\title{
Microfoundations of Influencing Public Opinion: Lobbying and Voting for Trade Policies
}

\author{
Derek Pyne \\ Memorial University of Newfoundland
}

\begin{abstract}
Public opinion, lobbying and elections have important effects on the formation of trade policy in democracies. This paper attempts to explain how lobbying expenditures can influence the outcome of an election fought over trade policy. Voters are assumed to own both capital and labour. The expenditures of lobby groups act as a signal to voters of the difference in returns to their factor endowments under different political parties.
\end{abstract}

- JEL classification: D72, D78, F13, F15

- Keywords: Trade Policy Formation, Tariffs, Voting, Lobbing

\section{Introduction}

This paper will attempt to offer an improved microfoundation to the political process underlying the endogenous trade policy literature. Much of the existing literature assumes that special interest groups expend funds in lobbying activities in response to positions parties currently hold on trade issues. ${ }^{1}$ It is sometimes assumed that these lobbying expenditures somehow affect the probability of a given party winning an election. ${ }^{2}$ However, in these models, the way in which the funds influence elections is either unclear or ad hoc. Other models assume that politicians are simply "bought off" in a manner that results in a welfare loss. ${ }^{3}$ If this were the whole story, given the large sums spent on influencing public policy, one

\footnotetext{
*Corresponding address: Derek Pyne, Department of Economics Memorial University of Newfoundland St. John's, Newfoundland A1C 5S7 Canada. Phone: 709-737-8107 Fax: 709-737-2094 E-mail: dpyne@ mun.ca (C2006-Center for International Economics, Sejong Institution, All Rights Reserved.
} 
would expect to observe politicians becoming much wealthier than they do in fact become. Many models do not even provide these microfoundations.

Some writers have addressed this problem. Two of the earliest writers to address this problem were Ronald Findlay and Stanislaw Wellisz (1983). ${ }^{4}$ They model the political process with a "tariff formation function". The result is analogous to a production function: "All the economist is concerned about is how the relevant 'inputs' are connected with the ultimate 'outputs', the details of the process of conversion in each case being inside a 'black box' (p. 471).

In a trade policy context, Wolfgang Mayer (1993) has assumed a HeckscherOhlin framework and modelled lobbying as the transmission of information from lobby groups to politicians. In a more general context, other writers have also modelled lobbying as involving the transmission of information between lobbyists and politicians. ${ }^{5}$

Wolfgang Mayer and Jun Li (1994) use a specific factor model. They assume that political parties use campaign contributions to reduce voter uncertainty regarding proposed tariff levels. Since voters are assumed to be risk adverse, this increases the likelihood of electors voting for the party in question. Both Mayer and Li (1994) and Mayer (1993) assume that voters have non-policy preferences that are not known with certainty by the political parties. This generates probabilistic voting. ${ }^{6}$

\footnotetext{
${ }^{1}$ One exception to this approach is the median voter framework adopted by Wolfgang Mayer (1984) and Philip I. Levy (1997). However, median voter models have their own shortcomings. For a general discussion of these shortcomings see Charles K. Rowley (1993a, 1993b). Another exception is the probabilistic voting model used by C.C. Yang (1995).

${ }^{2}$ Examples include Gene M. Grossman and Elhanan Helpman (1995), Gernot Sieg (1995), Stephen P. Magee, William A. Brock and Leslie Young (1989), Arye L. Hillman and Heinrich W. Ursprung (1988), Young and Magee (1986) and William A. Brock and Stephen P. Magee (1980, 1978).

${ }^{3}$ Examples of this approach include Martin Richardson (1994) and Dennis C. Mueller (2003). Anne O. Krueger (1974) raises the possibility that it is government officials who are bought off when import licences are awarded. A more general public choice paper that examines bribery in the political process is Eric Rasmusen and J. Mark Ramseyer (1994).

${ }^{4}$ A later but more thorough discussion of this problem is contained in David Austen-Smith (1991).

${ }^{5}$ Examples include, Susanne Lohmann (1995), Richard Ball (1995), David Austen-Smith and John R. Wright (1994, 1992), Austen-Smith (1993a, 1993b) and Eric Rasmusen (1993). See Austen-Smith (1997) for a survey of money and lobbying.

${ }^{6}$ For more information on probabilistic voting see Mueller (2003) and James Enelow and Melvin J. Hinich (1984).
} 
These papers make important contributions to the microfoundations of lobbying. Nonetheless, this paper takes the position that this is not the whole story when trade policy is concerned. Casual observation indicates that when trade issues (such as the ratification of the Canada-United States Free Trade Agreement) are concerned, lobby groups expend major resources in an effort to influence public opinion. In spite of this, very little attention has been devoted to providing microfoundations for the influencing of public opinion. This essay will attempt to take a step towards providing these microfoundations.

The model presented in this paper will assume that there are two political parties, each of which can commit to a tariff platform. Furthermore, it is assumed that the Stolper-Samuelson theorem holds. Moreover, it will assume that general voters know the Stolper-Samuelson theorem. ${ }^{7}$ However, voters do not know the precise quantitative effects the tariff positions of the political parties will have on the returns to capital and labour. This is because the cost of becoming informed is greater than the expected benefits of casting an informed vote. Since voters are endowed with both capital and labour, they must form some expectation of the relative returns in order to cast a vote.

It is assumed that there are two lobby groups that are each highly endowed with a different factor of production. This means that the difference in returns of the respective platforms have a significant effect on each lobby group. Thus, if they can influence the outcome of an election, the lobby groups have an incentive to become informed about the precise effects of the different policies. Voters, in turn, know that lobby groups have this information. Lobby groups, in turn, would like to communicate a message to voters that the difference in the rate of return, for their factor, under the different parties is infinitely large. The problem is that voters know the lobby groups have an incentive to exaggerate the difference. This paper will attempt to show that the spending of the lobby groups can act as a signal from the lobby groups to voters of the differences in factor returns between the platforms of each party. However, the exact capital-labour ratio of the median voter is unknown (although the distribution it is drawn from is known). Consequently, elections will have a probabilistic nature.

${ }^{7}$ For empirical evidence that voters cast their ballots as if they understand the Stolper-Samuelson theorem see Eugene Beaulieu (2002) and Edward J. Balistreri (1995, 1997). For empirical evidence that lobby groups behave as if the Stolper-Samuelson theorem holds see Derek Pyne (1997, 2000). Examples of endogenous trade policy models that make use of the Stolper-Samuelson relationship include Levy (1997), Yang (1995), Mayer (1993, 1984), Magee, Brock and Young (1989) and Young and Magee (1986). 
The next section will present the basic model. Section 3 will investigate implications of the basic model. Section 4 will allow for free-riding by members of the lobby groups. Section 5 will consider a slightly more elaborate signalling process where voters use the signals to infer the position of a "factor returns possibility curve". Section 6 will conclude the paper.

\section{The Basic Model}

In this model, it is assumed that there are two political parties, two lobby groups, $\mathrm{n}$ voters and two factors of production. Furthermore, it is assumed that it is common knowledge that the country in question is capital abundant. The order of moves is depicted in Figure 1. Following Magee, Brock and Young (1989), a Stackelberg hierarchy is assumed. Thus, it is assumed that the political parties behave as Cournot competitors with respect to each other but as Stackelberg leaders with respect to lobbyists and voters. Lobby groups behave as Stackelberg followers with respect to the political parties, Cournot competitors with respect to other lobby groups and Stackelberg leaders with respect to voters. Voters behave nonstrategically. Thus, this section will first examine the behaviour of voters. Then it will examine the behaviour of lobby groups and then the behaviour of political parties. ${ }^{8}$

Following Mayer and Li (1994) and Magee, Brock and Young (1989), the issues

\section{Figure 1.}

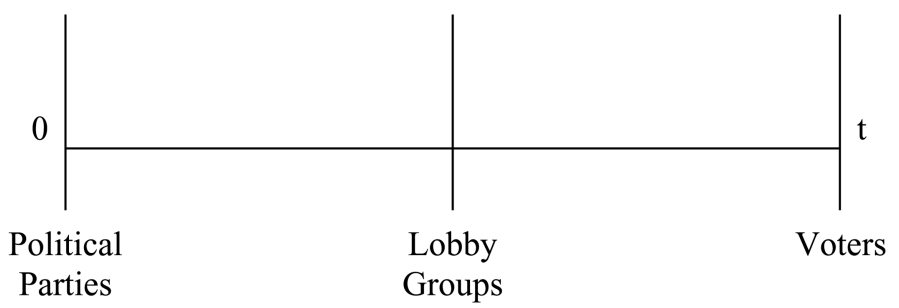

\footnotetext{
${ }^{8}$ Austen-Smith has justified this order of moves on the grounds that it is illegal for interest groups to explicitly buy policies:

It is illegal for interest groups explicitly to buy specific policies, so they promote politicians whose positions they support or seek to influence decisions through nonpecuniary action. Recognizing this, politicians have an incentive to adopt platforms to induce support from groups; hence the assumption that parties are first movers who take account of lobbies' responses when choosing their platforms. (Austen-Smith, 1991, p. 76)
} 
of changes in relative prices and the distribution of tariff revenues will be ignored. The Stolper-Samuelson theorem states that tariffs lead to an increase in the real return to the relatively scarce factor of production (Wolfgang Stolper and Paul A. Samuelson [1941]). Likewise, the real return to the relatively abundant factor of production will decrease.

If tariff revenues are distributed in an exogenous fashion (as is usually assumed), the question of the distribution of tariff revenues is also not a major problem. This is true as long as a voter's expectations of the tariff revenues he will be receiving are independent of the behaviour of the lobbyists. Furthermore, the revenues only amount to $3 \%$ of total government expenditures in advanced industrial countries (Magee, 1997).

For simplicity, it is also assumed that there is no free riding within the lobby groups. This assumption will be relaxed in section 4 .

It is assumed that voters earn income by renting out their factors of production. It is also assumed that they seek to maximize their expected income. Each voter i $(L \neq i \neq K)$ has income $\mathrm{I}^{\mathrm{i}}$ such that

$$
I^{i}=r^{j} K^{i}+w^{j} L^{i}
$$

where $\mathrm{K}^{\mathrm{i}}=$ the capital endowment of individual $\mathrm{i}$

$\mathrm{L}^{\mathrm{i}}=$ the labour endowment of individual $\mathrm{i}$

$\mathrm{I}^{\mathrm{i}}=$ the income of individual $\mathrm{i}$

$\mathrm{r}^{\mathrm{j}}=$ the return to capital if party $\mathrm{j}$ wins the election

$\mathrm{w}^{\mathrm{j}}=$ the return to labour if party $\mathrm{j}$ wins the election

$\mathrm{j}=\mathrm{F}, \mathrm{P}$.

Therefore, it is assumed that the only income individuals have are the returns to their capital and labour endowments.

Individual $\mathrm{i}$ will only vote for free trade party $\mathrm{F}$, if his expected income when party $\mathrm{F}$ wins the election is at least as great as his expected income when the protectionist party, $\mathrm{P}$, wins the election ${ }^{9}$. In this case, the following condition will hold:

$$
E\left(r^{F} K^{i}+w^{F} L^{i}\right) \geq E\left(r^{p} K^{i}+w^{p} L^{i}\right)
$$

\footnotetext{
${ }^{9}$ The actual party platforms will be endogenously determined later in the paper.
} 
Which can be written as

$$
K^{i} E\left[r^{F}-r^{P}\right] \geq L^{i} E\left[w^{P}-w^{F}\right]
$$

Hence, the individual must form expectations of the expected difference in factor returns if a given party is elected and its opponent is defeated ${ }^{10}$. For now, it will simply be assumed that voters use the expenditures of the lobby groups as signals of the returns. ${ }^{11}$ More precisely, it is assumed that the individual's expectation can be represented by some function $\mathrm{g}_{\mathrm{K}}^{\mathrm{i}}$, such that

$$
g_{K}^{i}\left(\frac{c^{K}}{K^{K}}, \frac{c^{L}}{L^{L}}\right)=E\left[r^{F}-r^{P}\right]
$$

$$
\begin{aligned}
& \text { where } \frac{\partial g_{K}^{i}}{\partial\left(\frac{c^{K}}{K^{K}}\right)}>0 \forall i \\
& \mathrm{~L}^{\mathrm{L}}=\text { the labour lobby's endowment of labour } \\
& \mathrm{K}^{\mathrm{K}}=\text { the capital lobby's endowment of capital } \\
& \mathrm{c}^{\mathrm{L}}=\text { the labour lobby's expenditure on lobbying } \\
& \mathrm{c}^{\mathrm{K}}=\text { the capital lobby's expenditure on lobbying }
\end{aligned}
$$

It is assumed that $\mathrm{g}^{\mathrm{i}} \mathrm{K}$ is continuous and twice differentiable. Indeed, in this essay it will be assumed that all functions are continuous and twice differentiable. For most of this paper it will be assumed that the capital lobby is only trying to signal the difference in returns to capital and not the difference in the returns to labour. Nevertheless, since lobbying expenditures are determined simultaneously, $\mathrm{g}^{\mathrm{i}} \mathrm{K}$ will in general be a function of the lobbying expenditures of both lobby groups.

\footnotetext{
${ }^{10}$ If voters knew whether their capital-labour ratio was greater or less than that of the economy as a whole, this information would not be necessary (Mayer, 1984). Thus, it is implicitly assumed that voters do not have this information. Although, it is likely that many voters at the extreme ends of the income distribution would have this information, it is reasonable to assume that many voters in the centre of the income distribution would not have this information.

${ }^{11}$ At this stage, it makes no difference whether the lobby group spends the funds directly or makes a contribution to a political party, provided the voter can observe the amount involved. Later it will be demonstrated that voter expectations are consistent with the maximizing behaviour of lobby groups.
} 
Using analogous reasoning, the individual's expectation of the difference in the return to labour is given by

$$
g_{L}^{i}\left(\frac{c^{L}}{L^{L}}, \frac{c^{K}}{K^{K}}\right)=E\left[w^{P}-w^{F}\right]
$$

where $\frac{\partial g_{L}^{i}}{\partial\left(\frac{c^{L}}{L^{L}}\right)}>0 \forall i$

The lobby groups will take the behaviour of voters into account when deciding on the level of their lobbying expenditures. Consider the capital lobby. It is assumed that it does not know the specific capital-labour ratio of the median voter but it does know the general distribution that the capital-labour ratio of the median voter is drawn from and that $\partial g_{K}^{i} / \partial\left(\mathrm{c}^{\mathrm{K}} / \mathrm{K}^{\mathrm{K}}\right)>0$ for all $\mathrm{i}^{12}$. This means that the outcome of elections is uncertain. The capital lobby is assumed to maximize the following objective function:

$$
\max _{c}^{k}\left\{\left[p\left(\frac{c^{K}}{K^{K}}, \frac{c^{L}}{L^{L}}\right) r^{F}+\left(1-p\left(\frac{c^{K}}{K^{K}}, \frac{c^{L}}{L^{L}}\right)\right) r^{P}\right] K^{K}-c^{K}\right\}
$$

such that $c^{K} \geq 0$

Where $\mathrm{p}\left(\frac{c^{K}}{K^{K}}, \frac{c^{L}}{L^{L}}\right)=$ the probability of the free trade party being elected.

It will be noted that the lobbying expenditures of the capital lobby do not come out of its capital endowment. Thus, it is implicitly assumed that the lobby groups have endowments not related to their capital and labour holdings. This is done for simplicity ${ }^{13}$. The first order conditions are given by

\footnotetext{
${ }^{12}$ It seems reasonable to assume that lobby groups and political parties would not know the specific capital-labour ratio of the median voter. Even if they knew the capital-labour ratio of every voter (a high information requirement) one would still need detailed information on voter turnout. This is an issue of much current research in public choice theory and is not addressed in this paper (for a brief survey of the issues, see Aldrich [1997]). This paper will simply follow Mayer (1984) who concludes: "depending on the specifically made assumptions on factor-ownership distributions and voting probabilities, different hypotheses on tariff determination can be developed".

${ }^{13}$ An earlier version of this paper had the capital lobby's contribution coming out of its endowment of capital and the labour lobby's contribution coming out of its endowment of labour. The results of this version hold in either case.
} 


$$
\begin{aligned}
& p_{K} r^{F}-p_{K} r^{P}-1 \leq 0 \\
& c^{K} \geq 0
\end{aligned}
$$

where $p_{K}=\frac{\partial p\left(\frac{c^{K}}{K^{K}}, \frac{c^{L}}{L^{L}}\right)}{\partial\left(\frac{c^{K}}{K^{K}}\right)}>0$

Assuming an interior solution, this can be written as

$$
p_{K}\left(r^{F}-r^{P}\right)=1
$$

The above is the familiar efficiency condition that the marginal benefit to an action is equal to its marginal cost.

The lobby's second order condition is

$$
p_{K K}<0
$$

$$
\text { where } p_{K K}=\frac{\partial^{2} p\left(\frac{c^{K}}{K^{K}}, \frac{c^{L}}{L^{L}}\right)}{2\left(\frac{c^{K}}{K^{K}}\right)^{2}}>0
$$

Thus, a sufficient condition for a maximum is for increased lobbying expenditures by the capital lobby to increase party F's probability of election at a decreasing rate.

The labour lobby's maximization problem is

$$
\max _{c}^{L}\left\{\left[p\left(\frac{c^{K}}{K^{K}}, \frac{c^{L}}{L^{L}}\right) w^{F}+\left(1-p\left(\frac{c^{K}}{K^{K}}, \frac{c^{L}}{L^{L}}\right)\right) w^{P}\right] L^{L}-c^{L}\right\}
$$

such that $c^{L} \geq 0$

Assuming an interior solution, the first and second order conditions are given below:

$$
p_{L}\left(w^{F}-w^{P}\right)=1
$$




$$
\begin{aligned}
\text { where } p_{L}= & \frac{\partial p\left(\frac{c^{K}}{K^{K}}, \frac{c^{L}}{L^{L}}\right)}{\partial\left(\frac{c^{L}}{L^{L}}\right)}<0 \\
p_{\mathrm{LL}}>0 \quad \text { where } p_{L L} & =\frac{\partial^{2} p\left(\frac{c^{K}}{K^{K}}, \frac{c^{L}}{L^{L}}\right)}{\partial\left(\frac{c^{K}}{L^{L}}\right)^{2}}
\end{aligned}
$$

The political parties will take the behaviour of lobby groups into account when deciding on a platform. Each party will do this by taking into account the fact that the contribution of the lobby groups is a function of the differences in the rates of returns between each party's regime. As Stackelberg leaders, the political parties will also take into account the fact that the level of $\mathrm{c}^{\mathrm{K}}$ is likely to be related to $\mathrm{c}^{\mathrm{L}}$ and vis versa. For example, in the case of the capital lobby, we can write its contribution function as $c^{\mathrm{K}}\left(\mathrm{r}^{\mathrm{F}}-\mathrm{r}, \mathrm{c}^{\mathrm{L}}\right)$. The rates of return are, in turn, a function of the tariff positions of the parties to $\mathrm{r}^{\mathrm{j}}\left(\mathrm{t}^{\mathrm{j}}{ }^{\mathrm{j}}\right.$ and to $\mathrm{w}^{\mathrm{j}}\left(\mathrm{t}^{\mathrm{j}}\right)$ for $\mathrm{j}=\mathrm{F}, \mathrm{P}$. Moreover, $\mathrm{c}^{\mathrm{L}}$ is a function of $\mathrm{c}^{\mathrm{K}}$ and $\mathrm{w}^{\mathrm{j}}(\mathrm{t})^{\mathrm{j}}$ for $\mathrm{j}=\mathrm{F}, \mathrm{P}$. Consequently, the signs of $\mathrm{dc}^{\mathrm{K}} / \mathrm{dt}^{\mathrm{F}}, \mathrm{dc}^{\mathrm{L}} / \mathrm{dt}^{\mathrm{F}}, \mathrm{dc}^{\mathrm{K}} /$ $\mathrm{dt}^{\mathrm{P}}$ and $\mathrm{dc}^{\mathrm{L}} / \mathrm{dt}^{\mathrm{P}}$ are not clear. To determine the signs of these derivatives let $\mathrm{f}^{\mathrm{K}}=0$ represent the first order condition for the capital lobby given in equation (8) (with terms suitably rearranged). Let $\mathrm{f}^{\mathrm{L}}=0$ represent the first order condition of the labour lobby given in equation (11). First consider the reactions of the two groups to changes in the position of the pro-capital party. Completely differentiating each first order condition with respect to $\mathrm{c}^{\mathrm{K}}, \mathrm{c}^{\mathrm{L}}$ and $\mathrm{t}^{\mathrm{F}}$ and putting the result in matrix form:

$$
\left[\begin{array}{ll}
\frac{\partial f^{k}}{\partial c^{k}} & \frac{\partial f^{k}}{\partial c^{L}} \\
\frac{\partial f^{L}}{\partial c^{k}} & \frac{\partial f^{L}}{\partial c^{L}}
\end{array}\right]\left[\begin{array}{l}
d c^{K} \\
d c^{L}
\end{array}\right]=\left[\begin{array}{c}
-\frac{\partial f^{k}}{\partial t^{F}} \\
-\frac{\partial f^{L}}{\partial t^{F}}
\end{array}\right] d t^{F}
$$

Using Cramer's rule, $\mathrm{dc}^{\mathrm{K}} / \mathrm{dt}^{\mathrm{F}}$ and $\mathrm{dc}^{\mathrm{L}} / \mathrm{dt}^{\mathrm{F}}$ can be represented by equations (14) and (15): 


$$
\begin{gathered}
\frac{d c^{K}}{d t^{F}}=\frac{-\frac{\partial f^{K}}{\partial t^{F}} \frac{\partial f^{L}}{\partial c^{L}}+\frac{\partial f^{L}}{\partial t^{F}} \frac{\partial f^{K}}{\partial c^{L}}}{\frac{\partial f^{K}}{\partial c^{K}} \frac{\partial f^{L}}{\partial c^{L}}-\frac{\partial f^{L}}{\partial c^{K}} \frac{\partial f^{K}}{\partial c^{L}}} \\
\frac{d c^{L}}{d t^{F}}=\frac{-\frac{\partial f^{L}}{\partial t^{F}} \frac{\partial f^{K}}{\partial c^{K}}+\frac{\partial f^{L}}{\partial t^{K}} \frac{\partial f^{L}}{\partial c^{K}}}{\frac{\partial f^{L}}{\partial c^{K}}-\frac{\partial f^{L}}{\partial c^{L}} \frac{\partial f^{K}}{\partial c^{K}}}
\end{gathered}
$$

From the second order conditions, it is clear that $\partial f^{K} / \partial c^{K}$ and $\partial f^{L} / \partial c^{L}$ are negative. Inspection of equations (8) and (11) reveals that $\partial f^{K} / \partial c^{L}$ and $\partial f^{L} / \partial c^{K}$ either have opposite signs or are identically equal to zero when $p$ is additively separable in $c^{\mathrm{K}}$ and $\mathrm{c}^{\mathrm{L}}$. Therefore, the denominators of (14) and (15) are positive. Hence, a sufficient condition for both $\mathrm{dc}^{\mathrm{K}} / \mathrm{dt}^{\mathrm{F}}$ and $\mathrm{dc}^{\mathrm{L}} / \mathrm{dt}^{\mathrm{F}}$ to be less than zero is for $\mathrm{p}$ to be additively separable in $\mathrm{c}^{\mathrm{K}}$ and $\mathrm{c}^{\mathrm{L}}$ and both $\partial f_{K} / \partial t^{F}$ and $\partial f_{L} / \partial t^{F}$ to be nonpositive. It should be noted that this is only a sufficient and not a necessary condition.

It is assumed that the only goal of the parties is to maximize their election chances. Accordingly, the objective function of the free trade party is given below and will be maximized with respect to $\mathrm{t}^{\mathrm{F}}$ :

$$
\max _{t^{F}}\left\{p\left(\frac{c^{K}\left(t^{F}, t^{P}, c^{L}\right)}{K^{K}}, \frac{c^{L}\left(t^{F}, t^{P}, c^{k}\right)}{L^{L}}\right)\right\}
$$

The first order conditions is

$$
\frac{p_{K}}{K^{K}} \frac{d c^{K}\left(t^{F}, t^{P}, c^{L}\right)}{d t^{F}}+\frac{p_{L}}{L^{L}} \frac{d c^{L}\left(t^{F}, t^{P}, c^{K}\right)}{d t^{F}}=0
$$

Using the signs of derivatives established before, we know that the first term of (17) is negative, and the second term is positive. This equation says that party $\mathrm{F}$ will decrease its proposed tariff level until the expected marginal benefit of an additional decrease is equal to its expected marginal cost (in terms of votes).

There are no clear (in the sense of derivatives having given signs) necessary or 
sufficient second order conditions. Thus, it will merely be assumed that the second order conditions hold.

Deriving $\mathrm{dc}^{\mathrm{K}} / \mathrm{dt}^{\mathrm{P}}$ and $\mathrm{dc}^{\mathrm{L}} / \mathrm{dt}^{\mathrm{P}}$ as was done for $\mathrm{dc}^{\mathrm{K}} / \mathrm{dt}^{\mathrm{F}}$ and $\mathrm{dc}^{\mathrm{L}} / \mathrm{dt}^{\mathrm{F}}$ (except here it is assumed that $\partial f_{K} / \partial t^{P}$ and $\partial f_{L} / \partial t^{P}$ are positive) results in both $\mathrm{dc}^{\mathrm{K}} / \mathrm{dt}^{\mathrm{P}}>0$ and $\mathrm{dc}^{\mathrm{L}} / \mathrm{dt}^{\mathrm{P}}>0$. Party $\mathrm{P}$ will maximize the following objective function with respect to $t^{\mathrm{P}}$ :

$$
\max _{t^{P}}\left\{1-p\left(\frac{c^{K}\left(t^{F}, t^{P}, c^{L}\right)}{K^{K}}, \frac{c^{L}\left(t^{F}, t^{P}, c^{K}\right)}{L^{L}}\right)\right\}
$$

The first order condition is

$$
\frac{p_{K}}{K^{K}} \frac{d c^{K}\left(t^{F}, t^{P}, c^{L}\right)}{d t^{P}}+\frac{p_{L}}{L^{L}} \frac{d c^{L}\left(t^{F}, t^{P}, c^{K}\right)}{d t^{P}}=0
$$

The interpretation of equation (19) is analogous to that of equation (17).

\section{A. Voters' Beliefs in Equilibrium}

For an equilibrium, it is necessary to show that voters' beliefs regarding the relationship between the differences in factor returns and the contributions of the lobby groups are correct in equilibrium. This section will show that functional forms exist which are consistent with an equilibrium. To do this we will first consider the relationship between the factor returns and the median voter's capital-labour ratio. Using inequality (3) we know that the median voter will vote for the pro-capital party when the following holds:

$$
\rho^{e}<\frac{K^{m}}{L^{m}}
$$

$$
\text { where } \begin{aligned}
\rho^{e} & =\frac{E\left[w^{P}-w^{F}\right]}{E\left[r^{F}-r^{P}\right]} \\
\mathrm{m} & =\text { the median voter. }
\end{aligned}
$$

As stated before, it is assumed that the political parties do not know the median voter's capital-labour ratio with certainty. However, the distribution it is drawn from is known. Therefore, the probability of the pro-capital party winning $\mathrm{p}(\rho)$ is equivalent to the probability of the median voter's capital-labour ratio being greater than $\rho^{\mathrm{e}}$. 
The objective functions of the capital and labour lobbies, respectively, are given as follows:

$$
\begin{aligned}
& \max _{c^{K}}\left\{K^{K} p\left(\rho^{e}\right) r^{F}+K^{K}\left(1-p\left(\rho^{e}\right)\right) r^{P}-c^{K}\right\} \\
& \max _{c^{L}}\left\{L^{L} p\left(\rho^{e}\right) w^{F}+L^{L}\left(1-p\left(\rho^{e}\right)\right) w^{P}-c^{L}\right\}
\end{aligned}
$$

In the above, $\mathrm{p}(\rho)$ is the probability that $\rho<\mathrm{K}^{\mathrm{m}} / \mathrm{L}^{\mathrm{m}}$. Hence, assuming no abstentions, $\mathrm{p}(\rho)$ is the probability that the free trade party will win the election. The first order conditions are given below:

$$
\begin{aligned}
& K^{K} \Delta r \frac{\partial p(\rho)}{\partial \rho^{e}} \frac{\partial \rho^{e}}{\partial c^{K}}=1 \\
& L^{L} \Delta w \frac{\partial p(\rho)}{\partial \rho^{e}} \frac{\partial \rho^{e}}{\partial c^{L}}=1
\end{aligned}
$$

where $\Delta r=r^{F}-r^{P}$

$$
\Delta w=w^{F}-w^{P}
$$

The voters know that there is a relationship between $\mathrm{c}^{\mathrm{K}}$ and $\mathrm{c}^{\mathrm{L}}$, and $\Delta r$ and $\Delta w$. Let the voter's perception of this relationship be represented by equation (25):

$$
\left(c^{K}, c^{L}\right)=H(\Delta r, \Delta w)
$$

This allows the following to be written:

$$
\begin{aligned}
-\frac{\Delta w}{\Delta r} & =\rho\left(c^{K}, c^{L}\right) \\
& =\rho[H(\Delta r, \Delta w)]
\end{aligned}
$$

Differentiating with respect to $\Delta \mathrm{w}$ and $\Delta \mathrm{r}$, respectively, and rewriting:

$$
\begin{aligned}
& -1=\Delta r\left[\frac{\partial \rho}{\partial c^{K}} \frac{\partial c^{K}}{\partial(\Delta w)}+\frac{\partial \rho}{\partial c^{L}} \frac{\partial c^{L}}{\partial(\Delta w)}\right] \\
& -\rho=\Delta r\left[\frac{\partial \rho}{\partial c^{K}} \frac{\partial c^{K}}{\partial(\Delta r)}+\frac{\partial \rho}{\partial c^{L}} \frac{\partial c^{L}}{\partial(\Delta r)}\right]
\end{aligned}
$$


Solving equations (23) and (24) for $\partial \rho / \partial c^{K}$ and $\partial \rho / \partial c^{L}$ respectively, substituting into equations

(27) and (28) and rewriting, results in the following:

$$
\begin{aligned}
& -\frac{\partial p(\rho)}{\partial \rho}=\frac{\partial c^{K}}{\partial(\Delta w)} \frac{1}{K^{K}}+\frac{\Delta r}{\Delta w} \frac{\partial c^{L}}{\partial(\Delta w)} \frac{1}{L^{L}} \\
& -\rho \frac{\partial p(\rho)}{\partial \rho}=\frac{\partial c^{K}}{\partial(\Delta r)} \frac{1}{K^{K}}+\frac{\Delta r}{\Delta w} \frac{\partial c^{L}}{\partial(\Delta r)} \frac{1}{L^{L}}
\end{aligned}
$$

Equations (29) and (30) define $\mathrm{c}^{\mathrm{K}}$ and $\mathrm{c}^{\mathrm{L}}$ as functions of $\Delta \mathrm{r}$ and $\Delta \mathrm{w}$.

It is only necessary to show that functional forms exist where voters' expectations are correct in equilibrium. With the following functional forms, equations (29) and (30) will hold:

$$
\begin{gathered}
c^{L}=\mathrm{L} \ln \Delta w+\mathrm{L} \ln \Delta r \\
c^{K}=\mathrm{K} \ln \Delta w+\mathrm{K} \ln \Delta r \\
\frac{\partial p(\rho)}{\partial \rho}=-\frac{1}{\rho \Delta r}-\frac{1}{\rho \Delta w}
\end{gathered}
$$

Thus, if these relationships hold and voters know equations (31) and (32) then an equilibrium exists.

\section{Implications}

This section will examine implications of the model developed in section 2 . Where possible, these results will be compared with those of the existing literature.

Consider the first proposition:

PROPOSITION 1: No lobbying expenditures will be made when political parties choose identical positions.

Proof: Reconsider the first order condition for the capital lobby:

$$
p_{K}\left(r^{F}-r^{P}\right)=1
$$

When $r^{\mathrm{F}}=\mathrm{r}^{\mathrm{P}}$, the marginal benefit of lobbying expenditures is zero while the marginal cost is equal to one. Hence, there will be no expenditures by the capital 
This non-participation in Hotelling races, by lobby groups, agrees with the findings of Magee, Brock and Young (1989) and Brock and Magee (1980). However, Mayer and Li (1994) and Mayer (1993) have found that lobby groups may still make campaign contributions when identical tariff positions are chosen. This is because their models assume that voters have non-policy preferences between the parties.

The next result has been called the contribution specialization theorem (Magee, Brock and Young [1989]). This states that a lobby will not make contributions to a party whose position is inferior (from the lobby's point of view) to that of another party. This result holds in Mayer and Li (1994) and Brock and Magee (1980). In Magee, Brock and Young (1989), these results hold subject to exceptions. These exceptions include: (1) imperfect information regarding $p,(2)$ access to the winning party is available in exchange for contributions, and (3) there are retribution (by the winning party) effects.

In this paper, information also plays a role. However, the role is different. Here, the contribution specialization theorem will not hold when voters have perfect information:

PROPOSITION 2: The party which lobby groups donate to is irrelevant when voters have perfect information regarding the amounts of the contributions. Otherwise, the lobbyists will only contribute to their favoured party. Inequality (3), and equations (4) and (5) indicate that what voters are concerned with are the amounts lobby groups are willing to spend in an effort to communicate information regarding the differences in factor returns between regimes. Consequently, where the money is spent is irrelevant, providing the cost is incurred. However, if voters can only observe the amounts political parties spend and do not know the source of these revenues, the situation is different. In this case, it seems reasonable to assume that voters will assume that the free trade party receives all its income from the capital lobby and that the protectionist party receives all its revenue from the labour lobby. Accordingly, there is no benefit in a lobby donating money to a party that does not have its preferred platform.

The next proposition has been called the reverse slope theorem by Magee, Brock and Young (1989) ${ }^{14}$ :

\footnotetext{
${ }^{14}$ This result can also be found in Brock and Magee (1980).
} 
PROPOSITION 3: The slopes of the political party reaction functions will have opposite signs near any equilibrium.

Proof: Rewrite the first order conditions for the free trade party as follows:

$$
p_{t^{F}}\left(t^{F}, t^{P}\right)=\frac{p_{K}}{K^{K}} \frac{d c^{K}\left(t^{F}, t^{P}, c^{L}\right)}{d t^{F}}+\frac{p_{L}}{L^{L}} \frac{d c^{L}\left(t^{F}, t^{P}, c^{K}\right)}{d t^{F}}=0
$$

Since a two party framework is assumed, the objective function of the high tariff party can be written as

$$
\min \mathrm{p}\left(t^{F}, t^{P}\right)
$$

As before, the first order condition can be written as follows:

$$
p_{t^{P}}\left(t^{F}, t^{P}\right)=\frac{p_{K}}{K^{K}} \frac{d c^{K}\left(t^{F}, t^{P}, c^{L}\right)}{d t^{P}}+\frac{p_{L}}{L^{L}} \frac{d c^{L}\left(t^{F}, t^{P}, c^{K}\right)}{d t^{P}}=0
$$

These first order conditions yield reaction functions of the form:

$$
\begin{aligned}
& t^{F}=R^{F}\left(t^{P}, a\right) \\
& t^{P}=R^{P}\left(t^{F}, a\right)
\end{aligned}
$$

where $\mathrm{a}=\mathrm{a}$ shift parameter.

The second order conditions are given below:

$$
\begin{aligned}
& \frac{d^{2} p}{d\left(t^{F}\right)^{2}}<0 \\
& \frac{d^{2} p}{d\left(t^{P}\right)^{2}}>0
\end{aligned}
$$

Except for the fact that $\mathrm{p}$ is defined as the probability of the low tariff party winning, rather than the high tariff party winning, the notation is now equivalent to that of Magee, Brock, and Young (1989). Hence, their proof holds. Nevertheless, it will be repeated for the convenience of the reader. Substitute (37) and (38) into equations (34) and (36), respectively:

$$
p_{t^{F}}\left(R^{F}\left(t^{P}, a\right), t^{P}\right)=0
$$




$$
p_{t}\left(R^{P}\left(t^{F}, a\right), t^{F}\right)=0
$$

Differentiating with respect to $\mathrm{t}^{\mathrm{F}}$ and $\mathrm{t}^{\mathrm{P}}$ :

$$
\begin{aligned}
& p_{t^{F_{t}} F^{F}} R_{t^{P}}^{F}+p_{t^{F_{t}{ }^{P}}}=0 \\
& p_{t^{P} t^{P}} R_{t}^{F}+p_{t^{P} T^{F}}=0
\end{aligned}
$$

Using Young's theorem and equations (43) and (44):

$$
R_{t^{F}}^{P}=\left[\frac{p_{t^{F}}}{p_{t^{P} t^{P}}}\right] R_{t^{P}}^{F}
$$

However, from the second order conditions it is clear that the bracketed term is negative. Consequently, the slopes of the reaction functions must have opposite signs near the equilibrium.

Q.E.D.

For ease of exposition, consider the case where $\mathrm{t}^{\mathrm{F}}$ is an export subsidy (that is, it's negative) and $\mathrm{t}^{\mathrm{P}}$ is a positive tariff. Thus, geometrically one axis can represent a tariff while the other represents a subsidy. The reverse slope theorem implies that all equilibria can be represented by one of two cases. In either case, one party is an enumerator. This means that the slope of its reaction function is positive. Accordingly, its special interest policy moves in the same direction as its opponent's policy. The other party is a counteractor. Thus, its reaction curve is negatively sloped. Hence, its special interest policy moves in the opposite direction of its opponent's platform. The two cases differ only with regard to which party is the enumerator and which party is the counteractor.

Since equivalent notation, first and second order conditions have been established, the following Magee, Brock and Young (1989) theorems must hold ${ }^{15}$ :

PROPOSITION 4: Assume that some shock causes both political parties to prefer a higher level of their redistribution policy. In equilibrium, the level of one of the policies must increase, but the other may fall.

PROPOSITION 5: Both parties could prefer increased redistribution, and yet the equilibrium redistributive policy might fall.

PROPOSITION 6: Although both parties may become increasingly polarized,

\footnotetext{
${ }^{15}$ These theorems assume that $\mathrm{t}^{\mathrm{F}}$ is negative and that the distortion free level of $\mathrm{t}$ is zero.
} 
the long run mean level of the two policy distortions could fall.

Propositions 4 and 5 have been called the reverse-shift theorem and the policy distance paradox, respectively. Both situations are more likely to occur (1) the more negative the slope of the counteractor's reaction curve, and (2) the greater the outward shift of the enumerator's reaction curve. When reverse-shifts occur, it is always the counteractor's policy that falls.

Proposition 6 has been called the distortion paradox. When the reverse-shift theorem holds, the distortion paradox is likely to occur when an increase in the policy of the high-distortion party leads to a large reduction in its probability of election. When the reverse-shift theorem does not hold, the distortion paradox is likely to occur when the party with a high probability of election reduces its policy significantly.

One implication of the existing literature that definitely does not seem to hold is that of optimal obfuscation. Optimal obfuscation is an attempt to explain why trade restrictions are used as a means of income redistribution rather than other more efficient methods such as taxes and subsidies which appear to be Pareto superior (Magee, Brock and Young [1989], Magee [1997] and Arye L. Hillman [1990], Robert E. Baldwin [1989]). The optimal obfuscation argument is that if a tax and subsidy were used to transfer income, general voters would know that they were being taxed to support a special interest group. Thus, general voters would be less likely to vote for a party which proposed such a system. Therefore, political parties will find more indirect ways of transferring resources. This way only the more informed voters (who are likely to be the lobby groups) will know what is occurring. The cost of this approach by the political parties is that the greater the degree of obfuscation, the fewer resources there are available to be transferred. This in turn reduces the value of the policy to the lobby groups and, hence, reduces their contributions to the political party. It is assumed that these two considerations lead the political party to adopt an optimal level of obfuscation. ${ }^{16}$

In the framework this essay adopts, it is assumed that all voters understand that a redistribution is taking place. Thus, the optimal obfuscation argument cannot hold. Other authors have offered alternative explanations. Magee (1997) has argued that tariffs are a major source of revenue for young countries and are easier for them to collect than other forms of taxation. Dani Rodrik (1986) has demonstrated that

\footnotetext{
${ }^{16}$ For a contrary view, see Donald Wittman (1989).
} 
when rent seeking is an increasing function of the efficiency of transfers, voters may decide at the constitutional stage to restrict the uses of more efficient transfers. ${ }^{17}$ Wolfgang Mayer and Raymond Riezman (1989) use a multidimensional voting model where individuals differ with respect to factor ownership, consumption preferences and tax treatment. They find that tariffs and not a tax and subsidy policy might be the outcome of the political process.

\section{Lobby Groups with Multiple Members}

The above analysis assumed that each lobby group either had a single member or no free riding. This paper will now consider the case of lobby groups with multiple members. To do this, it is important to know whether individual voters can observe the contributions of individual members of the lobby groups or, conversely, can only observe the total expenditures of the lobby group (as would be the case when donations are made to political parties who make expenditures which voters observe). The latter case will be examined first, followed by the former case.

Reconsider, the first order condition for the capital lobby when it only has a single member:

$$
p_{K}\left(r^{F}-r^{P}\right)=1
$$

The best a coalition can do when there are multiple members is to duplicate the outcome that occurs when there is a single member to a coalition. Accordingly, the above first order condition represents the optimum outcome for the capital lobby. Assume that there are $\mathrm{n}$ potential members in the capital lobby. Let $\mathrm{K}^{\mathrm{Kj}}$ represent the capital endowment of the $\mathrm{j}^{\text {th }}$ member of the capital lobby. Thus, $\sum_{j=1}^{n} K^{K j}=K^{K}$. The lobbying contribution of the $\mathrm{j}^{\text {th }}$ member of the capital lobby is given as $\mathrm{c}^{\mathrm{Kj}}$. Hence, $\sum_{j=1}^{n} c^{K j}=c^{K}$. This allows equation (8) to be rewritten as follows:

$$
p_{K} \sum_{j=1}^{n} \frac{K^{K j}}{K^{K}}\left(r^{F}-r^{P}\right)=1
$$

Consider the maximization problem of an individual member of the capital lobby:

\footnotetext{
${ }^{17}$ Another paper along similar lines is John Douglas Wilson (1990).
} 


$$
\max _{c^{K j}}\left\{p\left[\left(\frac{c^{K}}{K^{K}}, \frac{c^{L}}{L^{L}}\right) r^{F}+\left(1-p\left(\frac{c^{K}}{K^{K}}, \frac{c^{L}}{L^{L}}\right)\right) r^{P}\right] K^{K j}-c^{K j}\right\}
$$

such that $c^{K j} \geq 0$

The first order conditions are as follows, where one of the two weak inequalities must hold with equality:

$$
\begin{gathered}
p_{K} \frac{\left(K^{K j}\right)}{K^{K}}\left(r^{F}-r^{P}\right) \leq 1 \\
c^{K j} \geq 0
\end{gathered}
$$

Clearly, these optimal conditions differ from those of equation (46).

Clearly, the voter should take the free riding of the members of the lobby group into account when forming expectations of the net difference in the return to capital. To do this, two considerations arise. One is the relative size of the different members of the lobby group. The second consideration is the number of members of the lobby group. For simplicity, this paper will assume that each member of the lobby group is of equal size. This allows the first order condition of the capital lobby to be written as follows (assuming an interior solution):

$$
\frac{p_{K}}{n}\left(r^{F}-r^{P}\right)=1
$$

Clearly, the more members there are to a lobby group, the greater is the amount of free riding. Thus, $\partial g_{K}^{i}\left(\mathrm{c}^{\mathrm{K}} / \mathrm{K}^{\mathrm{K}}, \mathrm{c}^{\mathrm{L}} / \mathrm{K}^{\mathrm{L}}, \mathrm{n}, \mathrm{s}\right) / \partial n>0$ and $\partial g_{L}^{i}\left(\mathrm{c}^{\mathrm{L}} / \mathrm{K}^{\mathrm{L}}, \mathrm{c}^{\mathrm{K}} / \mathrm{K}^{\mathrm{K}}, \mathrm{s}, \mathrm{n}\right) / \partial s>$ 0 , where $\mathrm{s}$ is the number of members of the labour lobby group.

This has interesting implications for the relative effects of lobbying expenditures by capital and labour lobbies on voter expectations. In most countries, there are more firms than unions. Consequently, since the number of members in a lobby group is common knowledge, one would expect a given expenditure (relative to its endowment) by the capital lobby to have a greater influence on voter expectations than an equal expenditure by the labour lobby, ceteris paribus.

This also implies that free riding may not be a serious problem for lobby groups. Indeed, a lobby group would be better off if it could convince voters that it had a serious free riding problem since this would allow it to achieve the same effect on voter's expectations with smaller expenditures. 
The case where voters can observe the contributions of individual members of the lobby groups is somewhat different. For simplicity, it will be assumed that voters view lobby members as having perfect (or at least identical) information on factor returns. In this case, they know that members with a low $\mathrm{c}^{\mathrm{Kj}} / \mathrm{K}^{\mathrm{Kj}}$ are free riding more than those with a high $\mathrm{c}^{\mathrm{Kj}} / \mathrm{K}^{\mathrm{Kj}}$. Thus, they should consider the expenditures of members with a high $\mathrm{c}^{\mathrm{K}} / \mathrm{K}^{\mathrm{K}}$ to give a better indication of the differences in factor returns.

\section{Signals of a Factor Returns Possibility Curve}

This paper will now attempt to discuss two additional problems with the basic model. One is the fact that in the real world one lobby group will often accuse the other of attempting to buy an election. For example, in the 1988 Canadian election, the anti-free trade lobby group accused the pro-free trade lobby group of attempting to buy the election. In the basic model in section 2, this would only draw attention to the fact that the returns to capital must be great and thus people have a greater incentive to vote for the pro-free trade party.

Another problem involves the way in which people interpret the signals they receive. Since they know the Stolper-Samuelson theorem, one would think that they would know that there must exist a factor returns frontier of some kind. Thus, it is possible that at least some individuals would interpret an increase in the expenditures of the capital lobby as a sign of a decrease in the return to labour under the free trade party. Similarly, it is possible that at least some individuals will interpret an increase in expenditures by the labour lobby as a sign that the return to capital will be lower under the protectionist party.

These problems can be handled by generalizing the expectation functions defined in section 2. In this case, voters would interpret the contributions of the capital lobby as also being a signal of the difference in the returns to labour. Similarly, the spending of the labour lobby would be interpreted as a signal of the differences in the returns to capital under the two political parties. Thus, in this case the individual is receiving two signals of the difference between the returns to capital and two signals of the difference between the returns to labour. This would change the interpretation of the expectation functions but not the notation as the relevant terms already appear in the functions.

There are a number of ways in which a voter could interpret these signals. One is to assume that one of the signals is more accurate than the other. For example, it 
would seem reasonable for a voter to consider the spending of the capital lobby to be a better indicator of the difference in returns to capital than the spending of the labour lobby. Hence, he might totally ignore the spending of the labour lobby in forming his expectations of the returns to capital. Likewise, he might consider the spending of the labour lobby to be a better indicator of the returns to labour than the expenditures of the capital lobby. If this is the case, then $\partial g_{K}^{i} / \partial\left(\mathrm{c}^{\mathrm{L}} / \mathrm{L}\right)=0$ and $\partial g_{L}^{i} / \partial\left(\mathrm{c}^{\mathrm{K}} / \mathrm{L}^{\mathrm{K}}\right)=0$ (holding the direct relationship between $\mathrm{c}^{\mathrm{K}}$ and $\mathrm{c}^{\mathrm{L}}$ constant).

Consequently, the basic model of section 2 is simply a special case of this more general model.

A more general case would be to assume that voters put some weight on both signals. In this case, $\partial g_{K}^{i} / \partial\left(\mathrm{c}^{\mathrm{L}} / \mathrm{L}^{\mathrm{L}}\right)>0$ and $\partial g_{L}^{i} / \partial\left(\mathrm{c}^{\mathrm{K}} / \mathrm{K}^{\mathrm{K}}\right)>0$. Therefore, the capital lobby must take into account the effect its expenditures will have on voters' expectations of differences in labour returns. Similarly, the labour lobby must take the effect of its expenditures on voter's expectations of the differences in the returns to capital into account. This will reduce the level of their lobbying contributions. Moreover, members of a given lobby may want to remind voters who are relatively well endowed with their factor that the other lobby group is making major lobbying expenditures (or at least claim that this is the case).

The existence of a factor returns possibility curve raises an additional issue. If it is stable, voters are likely to have accurate expectations of status quo factor returns. Thus, a lobby group supporting a political party with a platform near the status quo will likely need to make smaller expenditures to signal factor returns under that party. Thus, the model would predict that in such situations, those trying to change the status quo will have to make larger expenditures on lobbying.

\section{Conclusions and Additional Caveats}

In a democracy, public opinion, lobbying and elections have important effects on the formation of trade policy. There is an extensive literature that deals with lobbying for trade policies and elections fought over trade policy. It often assumes that lobbying expenditures can influence the outcome of elections. Nonetheless, the way in which lobbying expenditures influence elections is often either ad hoc or unclear. This paper has attempted to provide microfoundations for the political process in endogenous trade policy models. Section 2 presented the basic model. It assumed that voters owned both capital and labour. They knew the qualitative but not the quantitative differences in factor returns under the tariffs of the two political 
parties. Lobby groups used lobbying expenditures as a signal to voters of the quantitative differences in factor returns. Section 3 compared the implications of this framework to those of the existing literature. Section 4 examined the effect free-riding would have on the equilibrium. Contrary to much of the existing literature, it found that free-riding would not necessarily reduce the effectiveness of the lobby groups. The penultimate section considered a slightly more elaborate signalling process where voters used the signals of the lobby groups to infer the position of a "factor returns possibility curve".

There are several real world examples that this framework might explain. For example, Canadian lobby groups aligned themselves as the Stolper-Samuelson theory predicts when it came to ratification of the Canada-United States Free Trade Agreement (Pyne 1997, 2000). Each made major expenditures of resources in an effort to influence the outcome of the 1988 election fought over the issue. Many would argue that in terms of economic theory, the content of the arguments made by the two sides were questionable. This model would predict that the intellectual content of the arguments was not the important factor. It was the large expenditures of resources themselves that would affect the formation of trade policy.

A few of the limitations of the model were not discussed earlier and need to be stated. ${ }^{18}$ One is that this paper assumes that trade policy can be represented by a continuous variable such as a tariff rate. Many issues in economic integration involve discrete choices. Examples include WTO membership and the introduction of the Euro. To this author, it seems likely that this framework could be adapted to such discrete choices. If so, as a referee pointed out, it is not so much a case of European political parties being pro-or anti-European. They are simply responding to lobbying efforts aimed at influencing voters.

This paper is best suited to analysing elections where the main issues concern broad changes in overall trade policy such as the British elections of 1906 and 1923 and the Canadian elections of 1911 and 1988. The two-good framework is not well suited to lobbying for the protection of specific product lines. Examples would include anti-dumping duties, technical regulations, import licensing and tariffs on a specific good. Moreover, these narrower issues sometimes have a role in national elections. ${ }^{19}$ The framework of this paper is not well suited to these issues as the general equilibrium effects are likely to be small. An interesting topic

\footnotetext{
${ }^{18} \mathrm{An}$ anonymous referee made the author aware of the importance of some of these limitations.

${ }^{19}$ An example would be the long-standing dispute over American duties on softwood lumber imports from Canada.
} 
for future research would be to apply the signalling framework of this paper to a specific factor trade model.

In a sense, the issue this paper addresses is a small part of a much larger question, which is how public opinion in general is influenced. Given the large sums spent on advertising, one would think that this question would already have been addressed in the mainstream economics literature. Nevertheless, this has not been the case. Thus, it seems safe to make one conclusion.

Given the state of the literature with regard to this larger question, much work still needs to be done.

\section{Acknowledgements}

This paper benefited significantly from the advice and suggestions of Sam Bucovetsky, Ruvin Gekker, Eli Katz, Michael Keen, Roger Latham, Jim Melvin, Gordon Myers, Al Slivinski and an anonymous referee. Any errors remaining are those of the author.

Received 12 May 2006, Accepted 23 June 2006

\section{References}

Aldrich, John H. (1997) When is it rational to vote? In Perspectives on public choice: A handbook, ed. Dennis C. Mueller, Cambridge University Press, Cambridge.

Austen-Smith, David. (1991) Rational consumers and irrational voters: A review essay on Black hole tariffs and endogenous policy theory, by Stephen Magee, William Brock and Leslie Young, Cambridge University Press 1989. Economics and Politics, 3(1), 73-92.

Austen-Smith, David. (1993a) Information and influence: Lobbying for agendas and votes. American Journal of Political Science, 37(3), 799-833.

Austen-Smith, David. (1993b) Campaign contributions and access. Papers in political economy, University of Western Ontario, London.

Austen-Smith, David. (1997) Interest groups: Money, information, and influence. In Perspectives on public choice: A handbook, ed. Dennis C. Mueller. Cambridge University Press, Cambridge.

Austen-Smith, David and Wright, John R. (1992) Competitive lobbying for a legislator's vote. Social Choice and Welfare, 9, 229-257.

Austen-Smith, David and Wright, John R. (1994) Counteractive lobbying. American Journal of Political Science, 38(1), 25-44. 
Baldwin, Robert E. (1989) The political economy of trade policy. Journal of Economic Perspectives, 3(4), 119-135.

Balistreri, Edward J. (1995) Preference revelation and the endogenous trade policy model: Empirical and experimental evidence for Stolper-Samuelson welfare effects. Ph.D. dissertation, University of Colorado.

Balistreri, Edward J. (1997) The performance of the Heckscher-Ohlin-Vanek model in predicting endogenous policy forces at the individual level. Canadian Journal of Economics, 30(1), 1-17.

Ball, Richard. (1995) Interest groups, influence and welfare. Economics and Politics, 7(2), 119146.

Beaulieu, Eugene. (2002) Factor or industry cleavages in trade policy?: An empirical analysis of the Stolper-Samuelson theorem. Economics and Politics, 14(2), 99-131.

Brock, William A. and Magee, Stephen P. (1978) The economics of special interest politics: The case of the tariff. American Economic Review, 68(2), 246-250.

Brock, William A., and Magee, Stephen P. (1980) Tariff formation in a democracy. In Current issues in commercial policy and diplomacy: Papers of the third annual conference of the international economics study group, ed. John Black and Brian Hindley, Trade Policy Research Centre, London.

Cassing, James H. (1991) Changes in trade-policy regimes. In Markets and politicians: Politicized economic choice, ed. Arye L. Hillman, Kluwer Academic Publishers, Boston.

Enelow, James and Hinich, Melvin J. (1984) The spatial theory of voting: An introduction, Cambridge University Press, Cambridge.

Feenstra, Robert C., and Bhagwati, Jagdish N. (1982) Tariff seeking and the efficient tariff. In Import competition and response, ed. Jagdish N. Bhagwati, University of Chicago Press, Chicago.

Findlay, Ronald and Wellisz, Stanislaw. (1982) Endogenous tariffs, the political economy of trade restrictions, and welfare. In Import competition and response, ed. Jagdish N. Bhagwati, University of Chicago Press, Chicago.

Findlay, Ronald and Wellisz, Stanislaw. (1983) Some aspects of the political economy of trade restrictions. Kyklos, 36, 469-481.

Grossman, Gene M. and Helpman, Elhanan. (1995) The politics of free-trade agreements. American Economic Review, 85(4), 667-690.

Hillman, Arye L. (1982) Declining industries and political-support protectionist motives. American Economic Review, 72(5), 1180-1187.

Hillman, Arye L. (1990) International trade policy. Benevolent dictators and optimizing politicians. Public Choice, 74, 1-15.

Hillman, Arye L. and Ursprung, Heinrich W. (1988) Domestic politics, foreign interests, and international trade policy. American Economic Review, 78(4), 729-745.

Krueger, Anne O. (1974) The political economy of the rent seeking society. American Economic Review, 64(3), 291-301.

Levy, Philip I. (1997) A political-economic analysis of free-trade agreements. American 
Economic Review, 87(4), 506-519.

Lohmann, Susanne. (1995) A signaling model of competitive political pressures. Economics and Politics, 7(3), 181-206.

Magee, Stephen P. (1997) Endogenous protection: The empirical evidence. In Perspectives on public choice: A handbook, ed. Dennis C. Mueller, Cambridge University Press, Cambridge.

Magee, Stephen P., Brock, William A., and Young, Leslie. (1989) Black hole tariffs and endogenous policy theory: Political economy in general equilibrium, Cambridge University Press, Cambridge.

Mayer, Wolfgang. (1984) Endogenous tariff formation. American Economic Review, 74(5), 970985.

Mayer, Wolfgang. (1993) Lobbying for tariff policies. Review of International Economics, $1(3), 221-233$.

Mayer, Wolfgang and Li, Jun. (1994) Interest groups, electoral competition, and probabilistic voting for trade policies. Economics and Politics, 6(1), 59-77.

Mayer, Wolfgang and Riezman, Raymond. (1989) Tariff formation in a multidimensional voting model. Economics and Politics, 1(1), 61-79.

Mueller, Dennis C. (2003) Public choice III. Cambridge University Press, Cambridge.

Pyne, Derek. (1997) The political economy of trade: A public choice approach. Ph.D. dissertation, York University.

Pyne, Derek. (2000) Revealed preference tests of the Stolper-Samuelson Theorem. The International Trade Journal, 24(4), 355-375.

Rasmusen, Eric. (1993) Lobbying when the decision maker can acquire independent information. Public Choice, 77, 899-913.

Rasmusen, Eric and Ramseyer, J. Mark. (1994) Cheap bribes and the corruption ban: A coordination game among rational legislators. Public Choice, 78, 305-327.

Richardson, David J. (1995) Income inequality and trade: How to think, what to conclude. Journal of Economic Perspectives, 9(3), 33-55.

Richardson, Martin. (1994) Why a free trade area?: The tariff also rises. Economics and Politics, 6(1), 79-96.

Rodrik, Dani. (1986) Tariffs, subsidies, and welfare with endogenous policy. Journal of International Economics, 21, 285-299.

Rowley, Charles K. (1993a) The relevance of the median voter theorem. In Homo economicus in the political market place. Vol. 1 of Public choice theory, ed. Charles K. Rowley. Aldershot: Edward Elgar Publishing. (First published in Journal of Institutional and Theoretical Economics, 140(1984), 104-126).

Rowley, Charles K. (1993b) Introduction. In Homo economicus in the political market place. Vol. 1 of Public choice theory, ed. Charles K. Rowley, Edward Elgar Publishing, Aldershot.

Sieg, Gernot. (1995) Theory of protectionism fluctuations caused by a support-maximizing government. Atlantic Economic Record, 23(4), 304-309.

Stolper, Wolfgang F. and Samuelson, Paul A. (1941) Protection and real wages. Review of 
Economic Studies, 9, 58-74.

Vousden, Neil. (1990) The economics of trade protection, Cambridge University Press, Cambridge.

Wilson, John Douglas. (1990) Are efficiency improvements in government transfer policies selfdefeating in political equilibrium? Economics and Politics, 2(3), 241-258.

Wittman, Donald. (1989) Why democracies produce efficient results. Journal of Political Economy, 97(6), 1395-1424.

Wood, Adrian. (1995) How trade hurt unskilled workers. Journal of Economics Perspectives, 9(3), 57-80.

Woodland, A.C. (1982) International trade and resource allocation, North-Holland Publishing Company, Amsterdam.

Yang, C.C. (1995) Endogenous tariff formation under representative democracy: A probabilistic voting model. American Economic Review, 85(4), 956-963.

Young, Leslie and Magee, Stephen P. (1986) Endogenous protection, factor returns and resource allocations. Review of Economic Studies, 53, 407-419. 